\title{
腰椎椎間孔外ヘルニアの手術成績
}

\author{
川添 泰 弘* 池田天 史* 宮 崎 真 一* 大 山哲 寛* \\ 土田徹* 安 藤 卓* 山城 和 馬* 橋 本 憲 蔵*
}

\section{Surgical Results of Extraforaminal Lumbar Disk Herniation}

\author{
Yasuhiro Kawazoe*, Takashi Ikeda*, Shin-ichi Miyazaki*, Tetsuhiro Oyama*, \\ Toru Tsuchida*, Takashi Ando*, Kazuma Yamashiro*, and Kenzo Hashimoto*
}

\begin{abstract}
当院では、2008 年 1 月以降腰椎椎間孔外ヘルニアに対して，Wiltse のアプローチによる顕微鏡視下外 側開空ヘルニア摘出術を施行している。その手術成績について，検討を行った。2008 年 1 月以降，腰椎 椎間孔外へルニアの診断で手術を行った 8 例（男性 5 例，女性 3 例）を対象とした。手術時平均年齢は 60.4 (42-74) 歳, 罹患高位は，L 4/5 6 例，L 5/S 2 例であった。平均手術時間 82 (45-155) 分，術中 出血量 40 (10-150) g であった. 術中, 術後を通して合併症は認めなかった。全例術翌日から離床開始し, 術後退院までの平均期間は20.3（11-41）日であった。JOA score は，術前 11.0 (6-17) 点が，最終経過 観察時 25.5 (20-27）点，平均改善率 80.6\% であった. Wiltse approach による顕微鏡視下外側開空へル ニア摘出術は，小切開で良好な視野が得られ，傍脊柱筋に対する侵襲も少なく，有用な方法である.
\end{abstract}

We have been performing microscopic lateral fenestration with Wiltse approach for extraforaminal lumbar disc herniation from January 2008. From then, 183 lumbar disc herniations were operated at our hospital. Among these cases, there were eight (five males and three females) extraforaminal lumbar disc herniation (4.4\%); six levels at L 4/5 and two at L 5/S. The average age was 60.4 years old (range, 42 74). The average duration of surgery was 82 minutes and average volume of blood loss was $40 \mathrm{ml}$. All patients were allowed to walk on the next day. There were no complications during surgery and no neurological deterioration after surgery. JOA score was improved from 11.0 (range, 6-17) to 25.5 (range, 20-27) postoperatively, and Hirabayashi's improved ratio was $80.6 \%$. The current study demonstrated that microscopic lateral fenestration with Wiltse approach provides good clinical results owing to minimal skin incision and minimal muscle damage.

Key words : extraforaminal lumbar disc herniation（腰椎椎間孔外ヘルニア), lateral fenestration (外側 開空術)， microsurgery（顕微鏡視下手術）

\section{は じめに}

腰椎椎間板ヘルニアは，春柱管内に発生する春柱管 内ヘルニアと, 椎間孔以遠に発生する外側ヘルニアに 大きく分けられ，さらに外側へルニアは，椎間孔内に 発生する椎間孔内ヘルニアと, それよりも外側に発生 する椎間孔外へルニアに分類される. 椎間孔外へルニ アに対しては,さまざまな手術法が報告されているが, 当院では, 2008 年 1 月以降, Wiltse のアプローチに よる顕微鏡視下外側開空へルニア摘出術を施行してい る.今回その手術成績について, 検討を行った.
対

象

2008 年 1 月以降, 2011 年 6 月までに当科にて施行 した腰椎椎間板ヘルニア全手術例 183 例のうち，椎間 孔外へルニアの診断で手術を行ったのは 8 例 (4.4\%) であった。男性 5 例，女性 3 例で，手術時平均年齢は 60.4（42～74）歳であった。罹患高位は L 4/5 6 例, L 5/S 2 例で, 術後平均経過観察期間は 10.4（6～16) ケ月であった。

\footnotetext{
* 熊本労災病院整形外科 Department of Orthopaedic Surgery, Kumamoto Rousai Hospital, Kumamoto, Japan
} 
結 果

手術は，全例多裂筋と最長筋の筋間より進入する Wiltse のアプローチにて, 顕微鏡視下に外側開空を 行い，ヘルニアを摘出した。平均手術時間は，多重根 のためへルニアの同定が困難であった 1 例と，再手術 のため時間を要した 1 例を含めて, $82(45 \sim 155)$ 分 であった。平均術中出血量は 40 （少量～150）g であ り, 術中合併症は認めなかった。

全例手術翌日から，マックスベルト装着の上離床を
開始した。手術後退院までの平均期間は20.3（11 41）日とやや長めであったが，これは，当院の近くに すぐに転院可能な後方病院が少ないという，地域的な 特性も影響している為と思われ，多くは，2 週間前後 で自宅退院可能であった。術前 JOA score は 11.0 (6 １7）点，平均経過観察期間 10.4 ヶ月での術後 JOA score は25.5（20２7）点，であり，平林法による平 均改善率は，80.6（60.9 91.3）％と，良好な結果で あった。また，術後合併症も特に認めなかった。
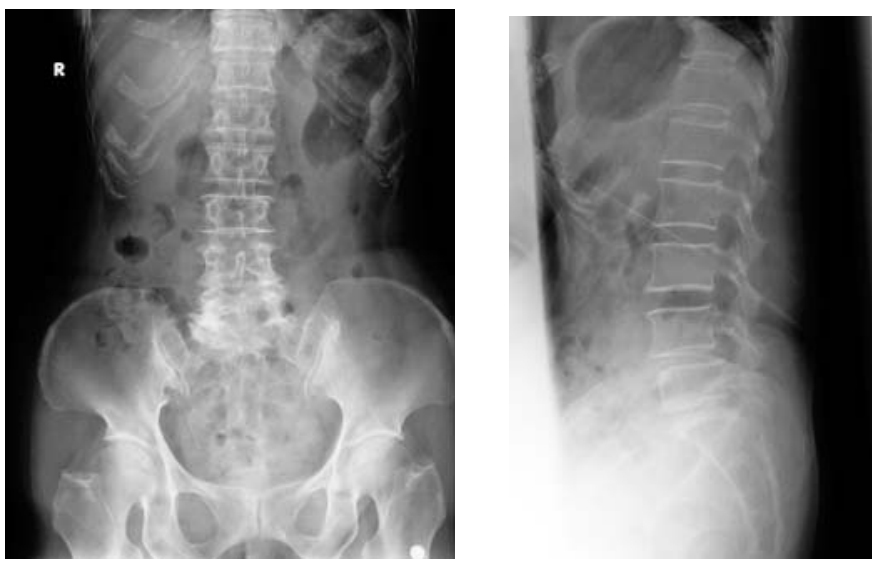

図 1 単純レントゲン

特に異常を認めない

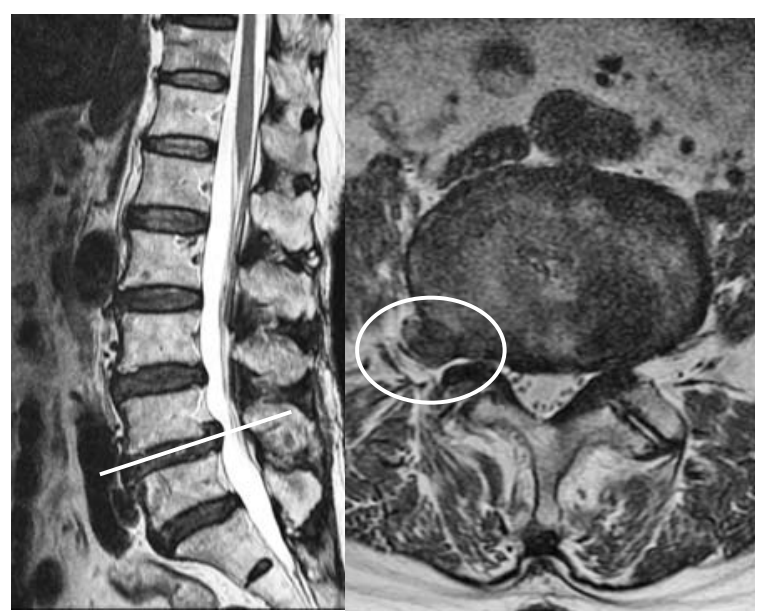

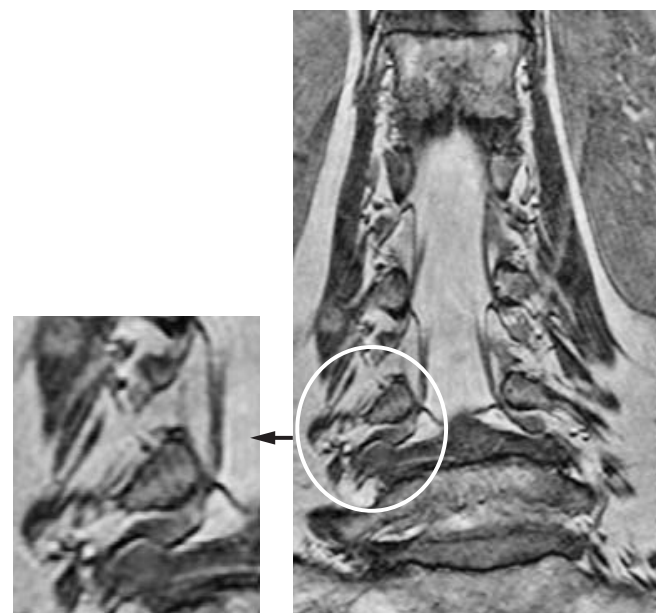

b

図 2 MRI

a：L 4/5 右椎間孔外にヘルニアを認める

b : 右 L 4 ルートは上方に圧迫され, 横走化している 


\section{症例}

74 歳 女性

主訴：右大腿神経痛

現病歴

1 週間くらい前から右大腿前面の痺れ，疼痛が出現し， 当科外来紹介受診. 疼痛強く歩行困難であったため, そのまま入院となった.

現症

大腿前面〜下腿内側にびりびりした痺れ感と軽度の知 覚障害を認め，FNST が強陽性であった。筋力は正常 であった。また，右膝蓋腱反射は健側と比べ低下して いた。以上より L 4 神経根症状が疑われた。

画像所見

単純レントゲンにては,特に異常を認めなかった（図 1 ). MRI axial 像に拈いて右 L 4/5 椎間孔外にへルニアを 認め（図 2 a), coronal 像では, 右 L 4 ルートがヘル ニアにより上方に圧迫され，横走化している所見を認 めた（図 $2 \mathrm{~b}$ ).

経過

L 4 神経根ブロックを行ったが，その効果は一時的で あり，手術を施行した。傍正中切開にて，多裂筋と最 長筋の筋間より深部を展開，L 5 上関節突起を約 3 $\mathrm{mm}$ 切除し，右 L 4 神経根と脱出したヘルニアを確認 し，これを摘出した。手術時間 60 分，出血量は $20 \mathrm{~g}$ であった，術後速やかに下肢痛は消失し，経過良好に て術後 12 日で自宅退院となった。JOA score は術前 12 点，術後 8 ケ月の最終観察時で 27 点，改善率は $88.2 \%$ であった。

\section{考察}

腰椎椎間孔外へルニアに対する手術進入法は，正中 からアプローチする方法と，外側からアプローチする 方法（Wiltse approach）がある。正中アプローチは， 脊柱管内から外側まで広く視野を確保できる利点があ るが，外側を展開するには比較的大きな切開が必要で ある．外側アプローチは，単独アプローチでは，春柱 管内病変に対処しづらいという欠点はあるが，病変が 切開部直下にあるため小切開にて手術が可能であり, また，筋間を進入するため，傍脊柱筋に対するダメー
ジが少ないという利点がある。椎間孔外へルニアであ れば，最短距離で病変まで到達でき，傍脊柱筋の筋組 織障害を最小限にする意味で，外側アプローチのほう が有用と思われる。

我々は顕微鏡を用いて，外側進入，外側開空術を施 行しているが，顕微鏡視下外側開密術については，諸 家においても良好な成績が報告されている吕36). また, 内視鏡を使用して行っている施設も多く，同様に良好 な成績が報告されている ${ }^{2445)}$ 。内視鏡は，より低侵襲 であり，明るく拡大された視野で，斜視鏡を使用すれ ば，椎間孔内まで広く確認することができるという利 点があるが， dis-orientation や learning curveの問題 などがある7). 椎間孔外ヘルニアであれば，顕微鏡視 下でも小切開にて最短距離で病変に到達ができ，椎間 孔内病変に対しても顕微鏡を傾けることで，ある程度 は対応可能あり，立体視が可能な顕微鏡は有用と考え る。我々の手術成績は，合併症もなく，短期成績では あるが，十分に満足のいく結果であった.

\section{ま と め}

腰椎椎間孔外ヘルニアに対する, Wiltse approach による顕微鏡視下外側開空へルニア摘出術は，小切開 で良好な視野が得られ，傍春柱筋に対する侵襲も少な く，有用な方法である。

\section{参 考 文 献}

1）濱中秀昭ほか：外側型腰椎椎間板ヘルニアの術後成績. J. Spine Res., 1 : 2144-2147， 2010.

2）生田 光，東野 修，田中孝幸：外側型腰椎椎間板へ ルニアに対する MED 法〜脱出部位による手術アプロー チの工夫〜。. Spine Res., 1：1691-1696，2010。

3）勝田佳樹ほか : 外側型腰椎椎間板ヘルニア手術例の検 討。中部整災誌，49：1067-1068，2006.

4）麻殖生和博ほか: 外側型腰椎椎間板へルニアに対して MED を用いた治療経験。中部整災誌，46：455-456, 2003.

5）園田康男，小橋芳浩：Wiltse approach による外側型腰 椎椎間板ヘルニア摘出術の小経験. J. Spine Res., 1： 2148-2151, 2010.

6）宇治郷諭ほか：外側型腰椎椎間板ヘルニア手術例の検 討．中四整災誌，20：195-198，2008.

7）吉田宗人ほか：腰椎椎間板ヘルニアに対する MEDの 適応と臨床成績. 臨整外，40：371-377，2005. 